\title{
Evaluation of Some Bread Wheat Cultivars under Different Seeding Rates and Weed Control Treatments
}

Mahmud, M. Sh. ${ }^{1}$; A. S. M. Morsy ${ }^{2}$ and A. A. O. Fakkar ${ }^{3}$

${ }^{1}$ Wheat Res. Dep., Field Crops Res. Inst., ARC, Egypt

${ }^{2}$ Department of Agronomy Faculty Agriculture Natural and Resources Aswan University Aswan 81528, Egypt.

${ }^{3}$ Weed Central Lab, Agric. Res. Center, Giza, Egypt

Email of auther:drahmed1122@yahoo.com

\section{ABSTRACT}

An experiment was conducted during 2014/2015 and 2015/2016 growing seasons at Shandaweel Agriculture Research Station, Sohag Governorate, Egypt to study the effect of two seeding rates (50 and $60 \mathrm{~kg} / \mathrm{fed})$, three bread wheat cultivars (Shandaweel-1, Sids12 and Giza-168) and six weed control treatments (Atlantis $\left(\mathrm{T}_{1}\right)$, Garnstar + Tpik $\left(\mathrm{T}_{2}\right)$, Garnstar + Axial $\left(\mathrm{T}_{3}\right)$, Garnstar + Traxos $\left(\mathrm{T}_{4}\right)$, hand weeding twice $\left(\mathrm{T}_{5}\right)$ and unweeeded control $\left(\mathrm{T}_{6}\right)$ )on weeds growth, yield and yield components of wheat. Split-split plot design with four replications was used. Results indicated that seeding rates were significantly on annual weeds $\left(\mathrm{g} / \mathrm{m}^{2}\right)$ and yield and yield components in both seasons. Increased seeding rate to $60(\mathrm{~kg} / \mathrm{fed})$ significantly decreased the dry weight of total weeds $\left(\mathrm{g} / \mathrm{m}^{2}\right)$ by 23.48 and $36.81 \%$ in first and second seasons, respectively compared to seeding rate of 50 (kg/fed).Seeding rate at 60 (kg/fed)give highest values of spike/length,No. of spikes $/ \mathrm{m}^{2}$ and grains yield (arad/fed) in both seasons. Wheat cultivars were significantly effect on dry weight of weeds in both seasons.Giza-168 cultivar decreased the dry weight of broad, grassy and total weeds by 19.98, 23.22 and $21.7 \%$ in the first season and by $25.02,30.58$ and $35.67 \%$ in the second season, respectively as compared to Sids-12cultivar.Wheat cultivarswere significantly effect of spike/length, No.of spikes $/ \mathrm{m}^{2}$, grains weight/spike,weight of spike and grains yield (arad/fed) in both seasons.Weed control treatments were significantly reduced dry weight of grassy, broad-leaved and total weeds $\left(\mathrm{g} / \mathrm{m}^{2}\right)$ in both seasonscompared to $\left(T_{6}\right)$. Using of $\left(T_{2}\right),\left(T_{4}\right)$ and $\left(T_{5}\right)$ twice gave the highestreduction the dry weight of grass, broad-leaved weed and total weeds in both seasons.Weed control treatments were significanteffect of spike length,No. of spikelets $/ \mathrm{spike,No}$. of spikes $/ \mathrm{m}^{2}$, No. of grains/spike,spikeweight,seed index and grains yield ( $\mathrm{arad} / \mathrm{fed}$ ) in both seasons. The interactions among highest seeding rate of $60 \mathrm{~kg} / \mathrm{fed}$, wheat Cultivar Giza 168 and $\left(\mathrm{T}_{5}\right)$ reduced dry weight of the grassy weeds by 94.9 and $97.3 \%$ in 2014/2015 and 2015/2016 seasons, respectively, and the dry weight of total weeds by $97.5 \%$ in 2015/2016 season as compared to sowing Sids-12 cultivar by seeding rate at $50 \mathrm{~kg} / \mathrm{fed}$ and unweededtreatment.Correlation analyses weresignificantly negative correlation with weight of grassy, broad-leaved and total weeds and yield in the first and second seasons, andsignificantly positive correlation between yield and its components in both seasons.Economic evaluation of the results indicated that seeding rates $60 \mathrm{~kg} / \mathrm{fed}$ with wheat cultivars Giza 168 and using of $\left(\mathrm{T}_{2}\right),\left(\mathrm{T}_{4}\right)$ and $\left(\mathrm{T}_{5}\right)$ gave the highest economic values, gross income, net income and profitability in the average of two seasons. Generally, cultivation Giza-168 at a rate $60 \mathrm{~kg} / \mathrm{fed}$ seed and application of (T2), (T4) and (T5)obtained by better crop of wheat under the experiment conditions.

\section{INTRODUCTION}

Wheatis considered to be the first strategic food crop in Egypt andsupplies about 20 percent of the food calories for the consumers. Also, wheat straw is an important fodder (Gomma, 1999). In Egypt, the total cultivated area of wheat reached 1.425 million hectares and the final production exceeded 9.0 million tons with an average of 6.0 t/ha (FAO, 2016). The gap between wheat production and consumption is about $40 \%$ of the national demand, it's imported from foreign markets. For these reasons,efforts should be done toward increasing and enhancing the wheat yield, in order to fill this gap.

Seeding rate strongly affects the capacity of wheat to utilize environmental resources because it affects the relative importance of intra-plant competition for light, water and nutrients during crop development (Tompkins $e t$ $a l, 1991$, a and b). The occurrence of lodging and diseases may increase at higher densities and leads to grain yield reduction. Low seed rate reduced competition, especially during vegetative growth, but increase intra-plant competition during filling because plants tend to produce more spike-bearing tillers (Marshall and Ohm, 1987). Tomar (2004) found that wheat grain yield was at the maximum with the highest seeding rate of 150 $\mathrm{kg} / \mathrm{ha}$.Ibrahim et al (2008) indicated that the interaction between sowing dates and wheatcultivars had a significant effect on grain yield and other characters as in plant height, days to heading and maturity, weight of grains/ spike and 1000 -grain weight. The highest grain yield was obtained when wheat was grown during Nov. Seed rate also affects the plant densities, No. of tillers $/ \mathrm{m}^{2}, 1000$-grain weight and biological yield Amanullah et al(2008).

Increasing wheat yield per unit area can be achieved by breeding high yielding cultivars and applying the optimum cultural practices such as seed rates and weed control treatment (Abd-Alla and Bassiouny, 1994). Wheat cultivars differed in yield and its components, superiority of Giza-168 cultivar with regard to grain yield and its components was investigated by many authors (Omar(2007), El-Ganayni and Mahmoud (2008), Hassan(2008), El-Nady (2009), Abd El-Ghany et al(2013), Mehasen et al(2014), Seadh (2014) and Abdrabbo et al (2016).Similarly,Kandil et al (2016) found that Giza-168 cultivar exceed (Shandweel-1 and Sides-12) cultivars in spik length, No. of grains/spik, grains weight/spik 1000grain weight and grain yield in the first and second seasons, respectively.

Weeds are one of the major constraints in wheat production as they reduce production due to competition Abbas et al(2009) indicated that crop losses due to weed competition allover the world as a whole, are greater than those resulting from combined effect of diseasesandinsects. It causes yield reduction in wheat from 10 to $65 \%$, Genene and Habtamu (2001). Application of herbicides significantly decreased dry weight of weeds as compared to dry weight in non-applied plots and increased wheat yield and yieldcomponents, Ashrafi et al(2009) and Bibi et al(2008) indicated that herbicidal control of weed must be considered in combination with other improved agronomic such as seed rates. Fakkar (2005) reported that the application of Topik at $100 \mathrm{cc} \mathrm{fed}^{-1}$. and hand weeding at 
30, 45 days after growing significantly increased plant height, spike length, weight of grains plant $^{-1}$, weight of grains spike ${ }^{-1}$ and grain yield fed $^{-1}$. Yasin et al (2010) found that clodinafop (Topic-15 WG) at rate of 37 g.a.i. ha ${ }^{-1}$ produced relatively less weed biomass, more plant height, wheat yield components and grain yield. Salahuddin et al (2016) showed that using of herbicidesimproved of wheat yield components and grain yield comparing with unweeded treatment.

The objective of this study aimed to study the effect of seeding rate, wheat cultivars and some weed control treatments on weeds growth, yield and yield components of wheat.

\section{MATERIALS AND METHODS}

The experiment was carried out at Shandaweel Agricultural Research Station, Agricultural Research Center, Sohag Governorate (Upper Egypt) in both winter growing seasons of 2014/2015 and 2015/2016. The preceding summer crop was maize in both seasons. Physical and chemical analysis of the soil of the experimental sites indicated that the soil was clay loam and containing of 35.0, 910 and $307 \mathrm{ppm}$ for N, P and $\mathrm{K}$, respectively with $8.52 \mathrm{pH}$ and total 1.26 of $\mathrm{N}$.

The sowing dates were $28^{\text {th }}$ and $25^{\text {th }}$ of November and harvested were $15^{\text {th }}$ and $18^{\text {th }}$ May in the $1^{\text {st }}$ and $2^{\text {nd }}$ seasons, respectively. The plot area was $10.5 \mathrm{~m}^{2}$.
Phosphorus fertilizer was applied as mono-calcium super phosphate $\left(15.5 \% \mathrm{P}_{2} \mathrm{O}_{5}\right)$ during preparation at the rate of $150 \mathrm{~kg} \mathrm{fed}^{-1}$. $\mathrm{N}$-fertilizer was added in the form of urea $(46.5 \% \mathrm{~N})$ at the rate of $75 \mathrm{~kg} \mathrm{~N}^{-1}$ in two equal portions before the first and second irrigation. The other recommended agricultural practices of growing wheat in the region were done. A split-split plot with RCBD design was used.Seeding rates were allocated in the main plots, the cultivars in the sup-plots and weed control treatments in the sub-sub plots as follows:

A-Main-plots: two seeding rates of 50 and $60 \mathrm{~kg} / \mathrm{fed}$.

B- Sub-plots: three broad wheat cultivars, Shandaweel1, Sids-12 and Giza-168.

C- Sub-Sub plots: Six weed control treatments were used as follows:

1 - Atlantis $42 \%$ OD (Iodosulfuron +Mesosulfuron) at $400 \mathrm{~cm} /$ fed at 30 days after sowing $\left(\mathrm{T}_{1}\right)$.

2- Granstar $75 \%$ DF (Tribenuron-methyl) at $8.0 \mathrm{~g} / \mathrm{fed}$ at 20 days after sowing+ +Topik 24\% (Clodinafoppropargyl) at $140 \mathrm{~g} /$ fed at 30 days after sowing $\left(\mathrm{T}_{2}\right)$.

3- Granstar + Axial 10\% EC (Pinoxaden) at $1.0 \mathrm{~L} / \mathrm{fed}$ at 30 days after sowing $\left(\mathrm{T}_{3}\right)$.

4- Granstar + Traxos $45 \% \mathrm{EC}$ at $500 \mathrm{~cm}^{3} /$ fed at 30 days after sowing $\left(\mathrm{T}_{4}\right)$.

5 - Hand weeding twice at 30-45 days after sowing $\left(\mathrm{T}_{5}\right)$.

6 - Unweeded (Control) $\left(\mathrm{T}_{6}\right)$.

Table 1. Trade, common and chemical names of the herbicides used in the study.

\begin{tabular}{lcc}
\hline Trade name & Common name & Chemical name \\
Atlantis 42\%OD & $\begin{array}{c}\text { Mesosulfuran methyl+indosulfuran methyl- } \\
\text { sodium. }\end{array}$ & $\begin{array}{c}\text { (Mesosulfuron 10g/L. + iodsulfuron 2g/L. +mefenpyr-diethyl } \\
\text { 30g/L.). }\end{array}$ \\
\hline Topik 15\% WP & Clodinafop- propargyl & $\begin{array}{c}\text { 2-propnil (®-2-[4-(5-chloro-3-fluoro-2- pyridnyloxy) } \\
\text { phenoxy]-propionate\}. }\end{array}$ \\
\hline $\begin{array}{l}\text { Axial 10\%EC } \\
\text { Granstar 75\% }\end{array}$ & Pinoxaden & $\begin{array}{c}\text { 8-(2,6-diethyl-4-methylphenyl)-1,2,4,5-tetrahydro-7-oxo-7H-pyrazolo } \\
\text { [1,2-d][1,4,5]oxadiazepin-9-yl 2,2-dimethylpropanoate. }\end{array}$ \\
$\begin{array}{lcc}\text { DF } \\
\text { Traxos 45\% EC }\end{array}$ & Tribenuron-methyl & $\begin{array}{c}\text { Pethyl 2-(N- (4-methoxy - 6 - methyl - 1,3,5 triazin 2 -cultivars [13, } \\
\text { 14]. Y) methylamine) caronyl)amino)sulful) benzoate. }\end{array}$ \\
\hline
\end{tabular}

\section{The following data were recorded:}

\section{1-Weed data:}

The dominant weed species in the present study were recorded: Avena spp. (wild oats) and Phalaris sp. (canary grass) as annual grassy weeds; Brassicasp. (Kabar, black mustard), Emexspinosus(spiny emex), Chenopodiumsp. (Lambsquarters), Ammi majus (common bishop) and Rumex dentatus (curly dock) as annual broadleaved weeds. The other weed species in rare infestation rates were Lolium sp. (ryegrass) as annual grassy weed and Anagallisarvensis (preinpernel), Beta vulgaris (wild beet, sea beet), Medicago polymorpha(medic, toothed medik), Melilotus indica (sweet clover) and Sonchus oleraceus (annual sowthistle) as annual broadleaved Weeds were hand pulled from one square meter randomly of each plot after 60 DAS (days after sowing), then identified into species and classified into the following two groups:

1-Dry weight ofgrassy weeds.

2-Dry weight of broad-leaved weeds.

3-Dry weight oftotal weeds: combined of grassy weeds and broad-leaved weeds.

Weeds were air dried for 3 days and dried onoven at $70 \mathrm{C}^{\circ}$ for 24 hours. Therefore, the dry weight of total weeds was recorded in gram $\mathrm{m}^{-2}$. Herbicides were sprayed by $\mathrm{Cp} 3$ knapsack sprayer with 200 litter of water fed ${ }^{-1}$.

\section{2-Yield and yield components of wheat:}

At harvest time, ten fertile stems were chosenrandomly from each sub-subplot for measuring, plant height $(\mathrm{cm})$, weight of spike $(\mathrm{g})$, No. of spikelets/spike, No. of grains/spike, weight of grain/spike, No. of spikes $/ \mathrm{m}^{2}$, counted in randomly chosen $\mathrm{m}^{2}$ in each plot, 100-seed weight $(\mathrm{g})$ and grain yield ( ardab fed $^{-1}$ )determined by threshing the harvested area in each plot $\left(10.5 \mathrm{~m}^{2}\right)$ and weighing the resulting grain.

\section{3- Correlation analysis:}

Asimple correlation matrix was carried out for the two seasons to investigate the relationships between dry weight different weed categories and wheat yield as well as between yield and its components to Steel and Torrie (1980).

\section{4-Economic evaluation:}

The economic evaluation of the experimental grain yield data was done using the methods described by CIMMYT (1988).

The economic evaluation included four estimates follows as: 
1 -Total cost $=$ cost of all operations in the production of wheat crop.

2-Gross income $=$ Price $($ L.E. /ard) $x$ Yield $($ ard $/$ fed $)$.

3 -Net income $=$ Gross income - Total income.

4-Benefit: cost ratio $(\mathrm{B} / \mathrm{C})=$ Gross income $/$ Total cost.

Price of the yield and the cost of agriculture practices were considered according to the Agriculture Research Center, Administration center of the Agriculture Extension in 2014/2015 and 2015/2016 seasons.

\section{5-Statistical analysis:}

The data were statistically analyzed according to techniqueanalysisof variance (ANOVA) for the splitsplit plot design as mentioned by Gomez and Gomez (1984) by mean of "MSTAT-C" computer software package and Least Significant Differences (LSD) at 5\% level of probability was calculated for compare between treatments means.

\section{RESULTS AND DISCUSSION}

\section{A-Effect of seeding rates,cultivarsand weed control treatments on dry weight of weeds: \\ I-Effect of seeding rates}

Data in Table 2 reported that seeding rates had significantly effect on dry weight of weeds $(\mathrm{g})$ in both seasons.Increasing seeding rateto60 $\mathrm{kg} / \mathrm{fed}$ reduceddry weight of broad, grassy and total weeds by $23.98,23.03$ and $23.48 \%$ and $35.55,38.40$ and $36.81 \%$ in the first and second seasons, respectivelyas combated to the rate of50 kg/fed in 2014/2015 and 2015/2016 seasons. These results might be due to increase the No. of plants with using rate of $60 \mathrm{~kg} / \mathrm{fed}$ which could decrease the numbers of weeds. Marwat et al(2002), Khan et al(2002), Zoheir et al(2009) and Meysam and Saeed (2015) supported these results.

\section{II- Effect ofwheat cultivars}

Table 2 showed that wheat cultivarshad significantly effect on dry weight of weeds in two seasons.Giza-168 cultivar decreased the dry weight of broad, grassy and total weeds by $19.98,23.22$ and $21.7 \%$ in the first season and by $25.02,30.58$ and $35.67 \%$ in the second season, respectivelyas compared to Sids-12 variety. Giza-168 variety of low dry weight of broad, grassy and total weeds followed by Shandaweel-1 cultivar due to vigor growth of these cultivarsand increase number of tillers and leaf area index than Sids-12cultivar.Sids12cultivar has the highest dry weight of broad, narrow and total weeds. These results are in good agreement with those obtained byAbouziena et al (2008).

\section{III- Effect of weed control treatments:}

Data in Table 2 show that the use ofweed control treatments were significantly reduced dry weight of total annual weeds in both seasons, as compared to $\left(\mathrm{T}_{6}\right)$.Atlantis at $400 \mathrm{~cm} / \mathrm{fed}$ at 30 days after sowing, Granstar at $8.0 \mathrm{~g} / \mathrm{fed}$ at 20 days after sowing+ Topik at $140 \mathrm{~g} /$ fed at 30 days after sowing , Granstar + Axial at $1.0 \mathrm{~L} / \mathrm{fed}$ at 30 days after sowing, Granstar + Traxos at $500 \mathrm{~cm}^{3} /$ fed at 30 days after sowing and hand weeding twice at 30-45 days after sowing decreased the dry weight of broad-leaved weeds by $88.45,93.23,88.33$, 92.32 and $94.25 \%$, grassy weeds by $86.31,88.8,85.60$, 90.99 and $91.22 \%$ and total weeds by $87.71,91.39$, 87.22, 92.23 and 93.55\% in 2014/2015 season, respectively as compared to $\left(\mathrm{T}_{6}\right)$. In $2015 / 2016$ seasons, $\left(\mathrm{T}_{1}\right),\left(\mathrm{T}_{2}\right),\left(\mathrm{T}_{3}\right),\left(\mathrm{T}_{4}\right)$ and $\left(\mathrm{T}_{5}\right)$ decreased the dry weight of broad-leaved weeds by $90.28,92.87,91.56,93.70$ and $94.52 \%$, grassy weeds by $84.68,88.06,86.09$, 88.01 and $88.05 \%$ ) and total weeds by $87.66,90.69$, $89.06,91.17$ and $91.69 \%$,respectively as compared to $\left(\mathrm{T}_{6}\right)$. These results may be due to that the application of $\left(\mathrm{T}_{1}\right),\left(\mathrm{T}_{4}\right)$ and $\left(\mathrm{T}_{2}\right)$ is a good measure for eradiating weeds during early growth period or during seedling. These treatments were efficiency in control of weeds because the weeds escape a weeding to likeness the weeds with wheat plants especially in early stages. These results are in harmony with those obtained byseveral researchers, such as El-Metwally and Saudy (2009), ElMetwally et al(2010), Tagour et al(2011),Shehzad et al (2012) and Ibrahim et al (2015).

Table 2. Effect of seeding rates, cultivarsand weed control treatments on dry weight of broad, grassy and total weeds $\left(\mathrm{g} / \mathrm{m}^{2}\right)$ in $2014 / 2015$ and $2015 / 2016$ seasons.

\begin{tabular}{|c|c|c|c|c|c|c|}
\hline \multirow[b]{2}{*}{ Treatments } & \multicolumn{3}{|c|}{$2014 / 2015$ season } & \multicolumn{3}{|c|}{ 2015/2016 season } \\
\hline & $\begin{array}{l}\text { Broad } \\
\text { weeds }\end{array}$ & $\begin{array}{c}\text { Grassy } \\
\text { weeds }\end{array}$ & $\begin{array}{c}\text { Total } \\
\text { weeds }\end{array}$ & $\begin{array}{l}\text { Broad } \\
\text { weeds }\end{array}$ & $\begin{array}{l}\text { Grassy } \\
\text { weeds }\end{array}$ & $\begin{array}{l}\text { Total } \\
\text { weeds }\end{array}$ \\
\hline \multicolumn{7}{|c|}{ A-Seeding rates } \\
\hline $50 \mathrm{~kg} / \mathrm{fed}$. & 86.54 & 95.07 & 181.61 & 83.13 & 66.01 & 149.14 \\
\hline $60 \mathrm{~kg} / \mathrm{fed}$. & 65.79 & 73.18 & 138.97 & 53.58 & 40.66 & 94.24 \\
\hline F. test & $* *$ & $* *$ & $* *$ & $* *$ & $* *$ & $* *$ \\
\hline \multicolumn{7}{|c|}{ B- Cultivars } \\
\hline Shandaweel1 & 74.23 & 84.06 & 158.29 & 66.28 & 51.81 & 118.09 \\
\hline Sids12 & 85.70 & 95.21 & 180.91 & 79.32 & 60.92 & 140.24 \\
\hline Giza168 & 68.58 & 73.09 & 141.67 & 59.47 & 42.29 & 101.76 \\
\hline L.S.D 0.05 & 6.80 & 4.71 & 7.32 & 4.88 & 4.82 & 3.34 \\
\hline \multicolumn{7}{|c|}{ C- Weed control treatments } \\
\hline$\left(\mathrm{T}_{1}\right)$ Atlantis & 37.34 & 43.97 & 81.31 & 29.09 & 29.69 & 58.78 \\
\hline$\left(\mathrm{T}_{2}\right)$ Garanstar +Topik & 21.89 & 35.99 & 57.88 & 21.33 & 23.14 & 44.47 \\
\hline$\left(\mathrm{T}_{3}\right)$ Garanstar + Axial & 137.73 & 46.26 & 83.99 & 25.25 & 26.96 & 52.21 \\
\hline$\left(\mathrm{T}_{4}\right)$ Garanstar + Traxos & 24.84 & 28.95 & 53.79 & 18.86 & 23.24 & 42.10 \\
\hline$\left(T_{5}\right)$ Hand weeding twice & 18.60 & 28.16 & 46.76 & 16.40 & 23.15 & 39.55 \\
\hline $\begin{array}{l}\left(\mathrm{T}_{6}\right) \text { Unweeded } \\
\text { (Control). }\end{array}$ & 323.24 & 321.26 & 644.50 & 299.31 & 193.79 & 493.10 \\
\hline L.S.D 0.05 & 5.57 & 5.33 & 7.88 & 3.54 & 3.70 & 4.22 \\
\hline \multicolumn{7}{|c|}{ Interaction } \\
\hline $\mathrm{A} \times \mathrm{B}$ & NS & $* *$ & NS & NS & ** & NS \\
\hline$A \times C$ & $* *$ & $* *$ & $* *$ & NS & $* *$ & NS \\
\hline $\mathrm{B} \times \mathrm{C}$ & $* *$ & $* *$ & $* *$ & NS & $* *$ & $* *$ \\
\hline $\mathrm{A} \times \mathrm{B} \times \mathrm{C}$ & NS & $* *$ & NS & NS & $* *$ & $* *$ \\
\hline
\end{tabular}

B-Effect of seeding rates, wheat cultivarsand weed control treatments on wheat yield and its components: 1-Effect of seeding rates:

Tables 3and 4 reveals that seeding rates have significantly influence onyield and its component in both seasons except with plant height and No. of grains/spike in both seasons, No. of spikelets /spike in 2014/2015 season and spike length and seed index in $2015 / 2016$ season. In 2015/2016 season the highest value of spike length $11.76 \mathrm{~cm}$ was obtained from sowing rate of $60 \mathrm{~kg} / \mathrm{fed}$ compared to $10.07 \mathrm{~cm}$ with the sowing by $50 \mathrm{~kg} / \mathrm{fed}$. The highest value of No. of spikes $/ \mathrm{m}^{2}$ in both season and No. of spikelets/spike in the second season was obtained from theseeding rate at of $60 \mathrm{~kg} /$ fedas compared to sowing by seeding rate of $50 \mathrm{~kg} / \mathrm{fed}$ due to increased number of wheat plants/unite area and decrease in weeds plant. Sowing by seeding 
rate $50 \mathrm{~kg} / \mathrm{fed}$ give the highest value of spike weight in the first season, grains weight/spike and seed index in both seasons than sowing by seeding rate at60 kg/fed, due to decreased the competition between wheat plant on nutrient and waterof soil. The highest valuesof grain yield 21.02 and 21.58 were obtained from seeding rate at $60 \mathrm{~kg} / \mathrm{fed}$ as compared with 19.10 and 19.68 at seeding rate of50 kg/fed in 2014/2015 and 2015/2016 seasons, respectively, due to increased No. of spike $/ \mathrm{m}^{2}$ and seed index. Higher yield with higher seed rate was also indicated by Ali et al (2010), Ahmed et al(2012) and Essam(2014). Similarly, Geleta et al (2002) found that $33 \%$ more grain yield from seeded wheat at 65 and 130 $\mathrm{Kg} / \mathrm{ha}$ as compared with the $16 \mathrm{Kg} / \mathrm{ha}$ seeding rate.

\section{$\mathbf{2}$ - Effect of wheat cultivarson yield and its component:}

Tables 3 and 4 show that wheat cultivarswere significantly effect on yield and its components in both seasons except plant height in both seasons,No. of spikelets/spike in the secondseason ,No. of grains/spike and seed index in the first season. Giza-168 have the greatest spike length, No. of spikelets/spike, No. of spikes $/ \mathrm{m}^{2}$, grains weight/spike, No. of grains/spike .spike weight, seed indexand grain yield followed by Shandaweel-1, but, Sids-12havethe lowest value of these traits. This true found in the two seasons of these experiments. The greatest grain yield (20.78 and 21.4 ardab/fed.) resulted from Giza-168 and the least grain yield (19.37 and 19.78 ardab/fed.) was obtained by Sids-12 in $2014 / 2015$ and 2015/2016 seasons, respectively. This increase in economic yield may be due to increase of spike length, No. of spike $/ \mathrm{m}^{2}$, No. of spikelet/spike, spike weight and seed index. These results are in line with those of Essam (2014) and Abdrabbo et al (2016).

\section{3 - Effect of weed control treatments on wheatyield and yield component:}

Data in Tables 3 and 4 shows that all weed control treatments were significantly effect on grain yield and its componentof wheatinboth seasons except plant height and grainsweight/ spike in the first season. $\left(\mathrm{T}_{5}\right)$ give the greatest values of spike length $(\mathrm{cm})$, No. of spikelets/spike, No. of spikes $/ \mathrm{m}^{2}$, grains weight of spike, No. of grains/spike,spike weight and seed index followed by $\left(\mathrm{T}_{4}\right),\left(\mathrm{T}_{2}\right)$ and $\left(\mathrm{T}_{3}\right)$, but, the value of these traits were resulted from $\left(\mathrm{T}_{1}\right)$ and $\left(\mathrm{T}_{6}\right)$, in both seasons. The maximum wheat grain yield ( $\mathrm{ard} / \mathrm{fed})$ was obtained by applying $\left(\mathrm{T}_{5}\right)$ and $\left(\mathrm{T}_{4}\right)$ they gave 21.62 and 21.11 ( $\mathrm{ard} / \mathrm{fed})$ in 2014/15 season and 22.61 and 22.14 ( $\operatorname{ard} /$ fed)in 2015/16 season compared with $\left(\mathrm{T}_{6}\right)(17.53$ and $18.52 \mathrm{ard} / \mathrm{fed}$ ) respectively, in 2014/2015 and $2015 / 2016$ seasons. It is argued that by $\left(\mathrm{T}_{4}\right),\left(\mathrm{T}_{2}\right),\left(\mathrm{T}_{3}\right)$ and $\left(\mathrm{T}_{5}\right)$ of weed control effectively reduced the weed population which led to better utilization of available resources and resulted in of maximum grain yield thus giving maximum 1000-grain weight. These results are in agreement with those found by Pandey et al(2001), Amit et al (2008) and Salahuddin et al (2016).

4- Effect of the interaction between seeding rates and wheat cultivarson dry weight of weeds and wheat grain yield and itscomponent:

The interaction among seeding rates and wheatcultivars under study hadinsignificant effect on broad-leaved, total weeds, grain yield and yield components in both seasons, except weight of grains/spike (g) in the first season and grassy weeds in two seasons. Data in Table 5reported that the interaction between wheatcultivars and seeding rates had a significant effect on weight of grassy weeds in both season and weight of grains/spike (g) in the first season. The lowest dry weight of grassy weeds $\left(62.05\right.$ and $\left.33.37 \mathrm{~g} / \mathrm{m}^{2}\right)$ was resulted from the interaction between seeding rate of $60 \mathrm{~kg} / \mathrm{fed}$ and Giza168 variety, but, the highest dry weight of grassy weed $\left(106.57\right.$ and $\left.81.37 \mathrm{~g} / \mathrm{m}^{2}\right)$ was obtained from the interaction amongseeding rate of $50 \mathrm{~kg} / \mathrm{fed}$ and Sids-12 cultivar in 2014/2015 and 2015/2016 seasons, respectively.Essam (2014) supported these trends.

Table 3. Effect of seeding rates, wheatcultivarsand weed control treatments on yield and yield component in 2014/2015 seasons

\begin{tabular}{|c|c|c|c|c|c|c|c|c|c|}
\hline Treatments & $\begin{array}{c}\text { No of } \\
\text { spikes } \\
/ \mathrm{m}^{2}\end{array}$ & $\begin{array}{c}\text { spike } \\
\text { length } \\
(\mathrm{cm})\end{array}$ & $\begin{array}{l}\text { No. of } \\
\text { spikelets } \\
\text { /spike }\end{array}$ & $\begin{array}{c}\text { Plant } \\
\text { height } \\
\text { (cm) }\end{array}$ & $\begin{array}{c}\text { grains } \\
\text { weight } \\
\text { /spike(g) }\end{array}$ & $\begin{array}{c}\text { spike } \\
\text { weight } \\
\text { (g) }\end{array}$ & $\begin{array}{c}\text { No. of } \\
\text { grains/ } \\
\text { spike }\end{array}$ & $\begin{array}{l}\text { Seed } \\
\text { index }\end{array}$ & $\begin{array}{c}\text { grain } \\
\text { yield } \\
\text { (ard/fed) }\end{array}$ \\
\hline \multicolumn{10}{|c|}{ A- seeding rates } \\
\hline $50 \mathrm{~kg} / \mathrm{fed}$. & 398.66 & 10.07 & 20.02 & 110.41 & 2.38 & 3.63 & 44.30 & 46.02 & 19.10 \\
\hline $60 \mathrm{~kg} / \mathrm{fed}$. & 431.89 & 11.76 & 19.64 & 112.34 & 2.11 & 3.28 & 43.30 & 43.51 & 21.02 \\
\hline F. test & $*$ & $*$ & NS & NS & $*$ & $*$ & NS & $*$ & $*$ \\
\hline \multicolumn{10}{|c|}{ B-Cultivars } \\
\hline 1- Shandaweel-1 & 413.18 & 10.69 & 20.46 & 110.49 & 2.27 & 43.61 & 3.44 & 45.02 & 20.02 \\
\hline 2- Sids-12 & 405.58 & 9.94 & 18.44 & 109.38 & 2.17 & 42.40 & 3.32 & 43.05 & 19.37 \\
\hline 3- Giza-168 & 427.07 & 12.05 & 20.59 & 114.26 & 2.30 & 46.02 & 3.60 & 46.23 & 20.78 \\
\hline L.S.D 0.05 & 15.05 & 0.18 & 0.42 & NS & 0.05 & NS & 0.14 & NS & 0.60 \\
\hline \multicolumn{10}{|c|}{ C- Weed control treatments } \\
\hline$\left(\mathrm{T}_{1}\right)$ Atlantis & 397.12 & 10.63 & 18.69 & 110.04 & 2.18 & 42.63 & 3.49 & 43.07 & 19.20 \\
\hline$\left(\mathrm{T}_{2}\right)$ Garanstar +Topik & 422.18 & 10.78 & 20.07 & 111.63 & 2.32 & 45.07 & 3.60 & 46.28 & 20.71 \\
\hline$\left(\mathrm{T}_{3}\right)$ Garanstar + Axial & 414.21 & 10.81 & 19.83 & 112.24 & 2.32 & 44.12 & 3.58 & 44.29 & 20.17 \\
\hline$\left(\mathrm{T}_{4}\right)$ Garanstar + Traxos & 426.93 & 11.56 & 20.46 & 112.63 & 2.41 & 47.61 & 3.71 & 46.39 & 21.11 \\
\hline$\left(\mathrm{T}_{5}\right)$ Hand weeding twice & 427.79 & 11.64 & 21.11 & 112.37 & 2.42 & 47.79 & 3.69 & 48.28 & 21.62 \\
\hline$\left(\mathrm{T}_{6}\right)$ Unweeded (Control). & 403.42 & 9.94 & 18.84 & 109.36 & 1.80 & 36.86 & 2.65 & 40.31 & 17.53 \\
\hline L.S.D ${ }_{0.05}$ & 14.38 & 0.73 & 0.19 & NS & NS & 1.71 & 0.07 & 1.69 & 0.97 \\
\hline \multicolumn{10}{|c|}{ Interaction } \\
\hline$\overline{A \times B}$ & NS & NS & NS & NS & $* *$ & NS & NS & NS & NS \\
\hline $\mathrm{A} \times \mathrm{C}$ & NS & NS & NS & NS & NS & $* *$ & NS & NS & NS \\
\hline $\mathrm{B} \times \mathrm{C}$ & NS & NS & NS & NS & NS & NS & NS & NS & NS \\
\hline $\mathrm{A} \times \mathrm{B} \times \mathrm{C}$ & NS & NS & NS & NS & NS & NS & NS & NS & NS \\
\hline
\end{tabular}


Table 4. Effect of seeding rates, wheatcultivarsand weed control treatments on yield and yield component in 2015/2016 seasons

\begin{tabular}{|c|c|c|c|c|c|c|c|c|c|}
\hline Treatments & $\begin{array}{c}\text { No of } \\
\text { spikes } \\
/ \mathbf{m}^{2} \\
\end{array}$ & $\begin{array}{c}\text { spike } \\
\text { length } \\
(\mathrm{cm})\end{array}$ & $\begin{array}{c}\text { No. of } \\
\text { spikelets } \\
\text { /spike } \\
\end{array}$ & $\begin{array}{c}\begin{array}{c}\text { Plant } \\
\text { height } \\
(\mathrm{cm})\end{array} \\
\end{array}$ & $\begin{array}{c}\text { grains } \\
\text { weight } \\
\text { /spike(g) }\end{array}$ & $\begin{array}{c}\text { spike } \\
\text { weight } \\
\text { (g) } \\
\end{array}$ & $\begin{array}{c}\begin{array}{c}\text { No. of } \\
\text { grains/ } \\
\text { spike }\end{array} \\
\end{array}$ & $\begin{array}{c}\text { Seed } \\
\text { index }\end{array}$ & $\begin{array}{c}\text { grain } \\
\text { yield } \\
\text { (ard/fed) }\end{array}$ \\
\hline \multicolumn{10}{|c|}{ A- seeding rates } \\
\hline $50 \mathrm{~kg} / \mathrm{fed}$. & 459.84 & 9.82 & 19.81 & 112.22 & 2.50 & 3.15 & 44.26 & 46.64 & 19.68 \\
\hline $60 \mathrm{~kg} / \mathrm{fed}$. & 557.73 & 10.84 & 21.15 & 111.20 & 2.31 & 3.54 & 44.78 & 44.86 & 21.58 \\
\hline F. test & $*$ & NS & $*$ & NS & $*$ & $*$ & NS & NS & $*$ \\
\hline \multicolumn{10}{|c|}{ B- Cultivars } \\
\hline Shandaweel-1 & 500.18 & 10.31 & 20.45 & 109.85 & 2.43 & 42.84 & 3.36 & 45.58 & 20.70 \\
\hline Sids-12 & 478.28 & 9.66 & 20.09 & 112.52 & 2.30 & 40.78 & 3.20 & 43.53 & 19.78 \\
\hline Giza-168 & 547.89 & 11.02 & 20.89 & 112.76 & 2.47 & 46.92 & 3.48 & 48.14 & 21.41 \\
\hline L.S.D ${ }_{0.05}$ & 8.20 & 0.76 & NS & NS & 0.05 & 2.72 & 0.08 & 3.18 & 0.56 \\
\hline \multicolumn{10}{|c|}{ C- Weed control treatments } \\
\hline$\left(\mathrm{T}_{1}\right)$ Atlantis & 499.33 & 9.38 & 19.57 & 110.01 & 2.40 & 41.32 & 3.37 & 44.05 & 19.82 \\
\hline$\left(\mathrm{T}_{2}\right)$ Garanstar + Topik & 524.65 & 10.74 & 21.01 & 112.10 & 2.47 & 45.59 & 3.48 & 47.94 & 21.84 \\
\hline$\left(\mathrm{T}_{3}\right)$ Garanstar + Axial & 514.57 & 10.25 & 20.71 & 114.20 & 2.43 & 43.06 & 3.41 & 45.19 & 21.10 \\
\hline$\left(\mathrm{T}_{4}\right)$ Garanstar + Traxos & 528.18 & 11.14 & 21.17 & 115.19 & 2.50 & 45.79 & 3.54 & 47.89 & 22.14 \\
\hline$\left(\mathrm{T}_{5}\right)$ Hand weeding twice & 536.08 & 11.37 & 21.24 & 114.58 & 2.56 & 46.47 & 3.56 & 48.62 & 22.61 \\
\hline$\left(\mathrm{T}_{6}\right)$ Unweeded (Control). & 449.87 & 9.09 & 19.17 & 104.17 & 2.06 & 36.87 & 2.70 & 40.82 & 18.52 \\
\hline L.S.D 0.05 & 9.06 & 0.58 & 1.03 & 1.33 & 0.09 & 2.85 & 0.09 & 2.23 & 0.81 \\
\hline \multicolumn{10}{|c|}{ Interaction } \\
\hline$\overline{\mathrm{A} \times \mathrm{B}}$ & NS & NS & NS & $\mathrm{NS}$ & NS & NS & NS & NS & NS \\
\hline $\mathrm{A} \times \mathrm{C}$ & NS & NS & NS & NS & NS & NS & NS & NS & NS \\
\hline $\mathrm{B} \times \mathrm{C}$ & NS & NS & NS & NS & NS & NS & NS & NS & NS \\
\hline $\mathrm{A} \times \mathrm{B} \times \mathrm{C}$ & NS & NS & NS & NS & NS & NS & NS & NS & NS \\
\hline
\end{tabular}

Table 5. Effect of the interaction between seeding rates and wheatcultivars on dry weight of grassy weeds $\left(\mathrm{g} / \mathrm{m}^{2}\right)$, weight of grain/spike (g) in 2014/2015 and 2015/2016seasons. 2014/2015 season 2015/2016 season

\begin{tabular}{llccc} 
Treatments & & $\begin{array}{c}\text { Weight of } \\
\text { grassy } \\
\text { weeds (g) }\end{array}$ & $\begin{array}{c}\text { grains } \\
\text { Weight }\end{array}$ & $\begin{array}{c}\text { Weight of }(\mathbf{g}) \\
\text { grassy } \\
\text { weeds (g) }\end{array}$ \\
\hline \multirow{2}{*}{ Kg } & Shandaweel-1 & 94.51 & 2.36 & 65.46 \\
& Sids-12 & 106.57 & 2.25 & 81.37 \\
& Giza-168 & 84.13 & 2.52 & 51.20 \\
\hline \multirow{2}{*}{ Kg/fed } & Shandaweel-1 & 73.61 & 2.17 & 38.15 \\
& Sids-12 & 83.88 & 2.08 & 50.47 \\
\cline { 2 - 5 } L.S.D & Giza-168 & 62.05 & 2.09 & 33.37 \\
\hline
\end{tabular}

5- Effect of the interaction between seeding rates and weed control treatments on dry weight of weeds and wheat grain yield and its components:

The interaction among seeding rates and weed control treatments had no significant effect on yield and its components in both seasons, except spike weight in the first season, but, it significantly affectedbroad and total weeds in the first season and grassy weeds in both seasons.Table 6show that the interaction between seeding rate of $60 \mathrm{~kg} / \mathrm{fed}$ and weed control by $\left(\mathrm{T}_{5}\right)$ resulted the best reduction in dry weight of broadleaved, grassy and total weeds in the first season. In the second season the interaction between seeding rate at 60 $\mathrm{kg} / \mathrm{fed}$ and weeds control by $\left(\mathrm{T}_{4}\right)$ or $\left(\mathrm{T}_{5}\right)$ significantly reduced grassy weeds than all interactions between seeding rates and weed control treatments. The lowest dry weight of grassy and total weeds resulted from the interaction effect between seeding rate at $50 \mathrm{~kg} / \mathrm{fed}$ and weed control by $\left(\mathrm{T}_{3}\right)$ in the $1^{\text {st }}$ season. The maximum of weight spike was resulted from seeding rate at $50 \mathrm{~kg} / \mathrm{fed}$ and weed control by $\left(\mathrm{T}_{5}\right)$, but the lowest value was obtained with seeding rate at $60 \mathrm{~kg} / \mathrm{fed}$ and $\left(\mathrm{T}_{6}\right)$.

Table 6. Effect of the interaction between seeding rates and weed control treatments on dry weight of weeds $\left(\mathrm{g} / \mathrm{m}^{2}\right)$, yield and yield component in $2014 / 2015$ and $2015 / 2016$ seasons.

\begin{tabular}{cccccc}
\hline \multirow{2}{*}{ Treatments } & \multicolumn{3}{c}{$\mathbf{2 0 1 4 / 2 0 1 5}$ season } & 2015/2016 season \\
\cline { 2 - 6 } & Grassy weeds & Broad leaved weeds & Total weeds Spike weight (g) & Grassy weeds \\
\hline Atlantis & 46.23 & 41.02 & 87.26 & 3.64 & 36.22 \\
Granstar +Topik & 35.30 & 21.98 & 57.28 & 3.81 & 27.57 \\
$50 \mathrm{Kg} /$ fed Granstar + Axial & 49.47 & 40.14 & 89.61 & 3.75 & 32.91 \\
Granstar + Traxos & 28.69 & 27.28 & 55.97 & 3.90 & 29.02 \\
Hand weeding twice & 29.98 & 15.58 & 45.56 & 3.92 & 28.37 \\
Unweeded (Control). & 380.68 & 373.30 & 753.98 & 2.74 & 241.86 \\
\hline Atlantis & 41.70 & 30.96 & 72.56 & 3.33 & 23.15 \\
Granstar +Topik & 37.74 & 16.90 & 54.64 & 3.39 & 18.70 \\
60 Kg/fed Granstar + Axial & 43.05 & 33.55 & 76.60 & 3.42 & 21.00 \\
Granstar + Traxos & 29.20 & 15.86 & 45.06 & 3.51 & 17.45 \\
Hand weeding twice & 25.58 & 12.80 & 38.38 & 3.46 & 17.93 \\
Unweeded (Control). & 261.88 & 284.71 & 546.59 & 2.56 & 145.72 \\
\hline L.S.D 0.05 & 7.99 & 7.88 & 11.15 & 0.07 & 5.23
\end{tabular}


6- Effect of the interaction among wheat cultivars and weed control treatments on dry weight of weeds and yield and its components:

The interaction between wheat cultivars and weed control treatments was significantly effectondry weight of broad-leaved weeds, grassy, total weeds $\left(\mathrm{g} / \mathrm{m}^{2}\right)$ in the first seasons and grassy, total weeds in the second season, but, not had significant effect on yield and yield components in both seasons. Table 7 show that the interaction between Giza-168 cultivar and weed control by $\left(\mathrm{T}_{5}\right)$ resulted the best reduction in dry weight of broad, grassy and total weeds in the first season, which did not significant than the interaction Giza-168 cultivar and weed control by $\left(\mathrm{T}_{4}\right)$ or Sandaweel-1 cultivar and weed control by $\left(\mathrm{T}_{5}\right)$. In the second season the interaction between Giza-168and weeds control by $\left(\mathrm{T}_{5}\right)$ reduced significantly grassy weeds than all interactions between cultivarsand weed control treatments. The least effect on grassy and total weeds in both seasons was resulted from the interactions between Sids-12 or Shandweel-1 cultivar and weed control by $\left(\mathrm{T}_{3}\right)$.

Table 7. Effect of the interaction between wheatcultivars and weed control treatments on dry weight of weeds $\left(\mathrm{g} / \mathrm{m}^{2}\right)$ in $2014 / 2015$ and $2015 / 2016$ seasons

\begin{tabular}{|c|c|c|c|c|c|c|}
\hline \multirow[b]{2}{*}{ Treatments } & & \multicolumn{3}{|c|}{2014 / 2015 season } & \multicolumn{2}{|c|}{2015 / 2016 season } \\
\hline & & $\begin{array}{c}\text { Grassy } \\
\text { weeds }\end{array}$ & $\begin{array}{c}\text { Broad leaved } \\
\text { weeds }\end{array}$ & $\begin{array}{c}\text { Total } \\
\text { weeds }\end{array}$ & Grassy weeds & $\begin{array}{l}\text { Total } \\
\text { weeds }\end{array}$ \\
\hline \multirow{6}{*}{ Shandaweel1 } & Atlantis & 43.05 & 32.82 & 75.87 & 28.44 & 59.65 \\
\hline & Granstar +Topik & 39.27 & 18.79 & 58.06 & 22.13 & 42.00 \\
\hline & Granstar + Axial & 48.52 & 34.77 & 83.29 & 25,55 & 50.94 \\
\hline & Granstar + Traxos & 28.69 & 20.68 & 49.37 & 20.22 & 38.07 \\
\hline & Hand weeding twice & 23.65 & 12.34 & 35.99 & 22.23 & 38.03 \\
\hline & Unweeded (Control). & 321.20 & 325.99 & 647.19 & 192.09 & 479.82 \\
\hline \multirow{6}{*}{ Sids12 } & Atlantis & 49.52 & 40.70 & 90.22 & 36.82 & 71.60 \\
\hline & Granstar +Topik & 39.82 & 21.50 & 61.32 & 29.44 & 55.86 \\
\hline & Granstar + Axial & 51.22 & 39.82 & 91.03 & 33.85 & 63.7 \\
\hline & Granstar + Traxos & 33.67 & 24.19 & 57.86 & 30.90 & 53.48 \\
\hline & Hand weeding twice & 37.53 & 16.74 & 54.27 & 34.05 & 53.97 \\
\hline & Unweeded (Control). & 359.58 & 371.22 & 730.80 & 230.45 & 572.58 \\
\hline \multirow{6}{*}{ Giza168 } & Atlantis & 39.33 & 34.30 & 73.64 & 23.80 & 44.85 \\
\hline & Granstar +Topik & 30.39 & 18.13 & 48.52 & 17.84 & 35.54 \\
\hline & Granstar + Axial & 39.05 & 35.80 & 74.85 & 21.47 & 41.72 \\
\hline & Granstar + Traxos & 24.57 & 19.75 & 44.32 & 18.60 & 34.74 \\
\hline & Hand weeding twice & 22.15 & 13.50 & 35.65 & 13.17 & 26.78 \\
\hline & Unweeded (Control). & 283.05 & 289.82 & 572.86 & 158.84 & 376.89 \\
\hline L.S.D 0.05 & & 7.99 & 7.88 & 19.31 & 6.41 & 7.31 \\
\hline
\end{tabular}

7- Effect of the interaction among seeding rates, wheatcultivars and weed control treatments on dry weight ofweeds and wheat grain yield and itscomponent:

The interaction among seeding rates, wheat cultivars and weed control treatments hada significant effect on dry weight of grassy weeds in the $1^{\text {st }}$ season, grassy and total weeds in the $2^{\text {nd }}$ season, but, did not significantly affected yield and yield components in both seasons. Table 8show that the interaction among seeding rate at $60 \mathrm{~kg} / \mathrm{fed}$, Giza-168 cultivar and weed control by $\left(T_{5}\right)$ gives the best reduction in dry weight of grassy weeds in the first season, grassy and total weeds in the second season, which did not significant than the interaction effect among seeding rate at $60 \mathrm{~kg} / \mathrm{fed}$, Giza168 cultivar and weed control by $\left(\mathrm{T}_{4}\right)$ or seeding rate of $60 \mathrm{~kg} / \mathrm{fed}$, Shandaweel-1 cultivar and weed control by $\left(\mathrm{T}_{5}\right)$, seeding rate at $60 \mathrm{~kg} / \mathrm{fed}$, Sandaweel- 1 cultivar and weed control by $\left(\mathrm{T}_{4}\right)$. The lowest effect on grassy weeds in the first season, grassy and total weeds in the second season wasobtained from the interactions among seeding rate at $50 \mathrm{~kg} / \mathrm{fed}$, Sids-12 cultivar and weed control by $\left(\mathrm{T}_{1}\right)$ or $\left(\mathrm{T}_{3}\right)$ (Table 8$)$.

\section{C- Correlation coefficients}

Results in Table 9 indicated that grain yield was positively and significantly correlated with spike length (0.992 and 0.914), No. of spikelets/spike (0.529 and $0.588)$, No of spikes $/ \mathrm{m}^{2}$ (0.651 and 0.872$)$, weight of grains/spike (0.339 and 0.557$)$, spike weight (0.465 and $0.855)$, No. of grains/spike (0.746 and 0.684) and seed index (0.489 and 0.391), in 2014/2015 and 2015/2016, respectively. This indicated that increased attributes, invariability resulted in increasing grain yield. These findings in most cases were in accordance with those obtained by Mondal and khadjura (2001), El.Ganayni and Mahmoud (2008), Hassan (2008) and Essam (2014). Meanwhile, grain yield was not significantly correlated with plant height 0.201 and 0.175 in 2014/15 and 2015/2016 seasons, respectively. Conversely, grain yield was negatively and significantly correlated with grassy -0.598 and -0.654$)$ broad-leaved $(-0.495$ and $0.587)$ and total weeds (-0.565 and -0.607$)$ in $2014 / 2015$ and 2015/2016 seasons. 
Table 8. Effect of interaction among seeding rates, wheatcultivarsand weed control treatments on dry weight of weeds $\left(\mathrm{g} / \mathrm{m}^{2}\right)$ in $2014 / 2015$ and $2015 / 2016$ seasons.

\begin{tabular}{|c|c|c|c|c|c|}
\hline & \multirow{2}{*}{\multicolumn{2}{|c|}{ Treatments }} & \multirow{2}{*}{$\begin{array}{c}2014 / 2015 \text { season } \\
\text { Grassy weeds }\end{array}$} & \multicolumn{2}{|c|}{$\begin{array}{c}2015 / 2016 \text { season } \\
\end{array}$} \\
\hline & & & & Grassy weeds & Total weeds \\
\hline \multirow{18}{*}{$50 \mathrm{Kg} / \mathrm{fed}$} & \multirow{6}{*}{ Shandaweel-1 } & Atlantis & 43.87 & 35.10 & 69.77 \\
\hline & & Granstar +Topik & 35.50 & 26.03 & 48.63 \\
\hline & & Granstar + Axial & 52.10 & 32.00 & 59.57 \\
\hline & & Granstar + Traxos & 27.13 & 28.10 & 51.23 \\
\hline & & Hand weeding twice & 24.57 & 29.23 & 50.13 \\
\hline & & Unweeded & 383.87 & 241.97 & 591.77 \\
\hline & \multirow{6}{*}{ Sids-12 } & Atlantis & 53.40 & 45.67 & 88.67 \\
\hline & & Granstar +Topik & 38.30 & 36.10 & 65.07 \\
\hline & & Granstar + Axial & 54.63 & 42.07 & 77.20 \\
\hline & & Granstar + Traxos & 34.40 & 36.87 & 65.33 \\
\hline & & Hand weeding twice & 42.13 & 37.27 & 62.87 \\
\hline & & Unweeded & 416.53 & 290.23 & 717.13 \\
\hline & \multirow{6}{*}{ Giza-168 } & Atlantis & 41.43 & 27.90 & 53.77 \\
\hline & & Granstar +Topik & 32.10 & 20.57 & 44.07 \\
\hline & & Granstar + Axial & 41.67 & 24.67 & 48.60 \\
\hline & & Granstar + Traxos & 24.70 & 22.10 & 42.60 \\
\hline & & Hand weeding twice & 23.23 & 18.60 & 35.73 \\
\hline & & Unweeded & 341.63 & 193.37 & 512.37 \\
\hline \multirow{18}{*}{$60 \mathrm{Kg} / \mathrm{fed}$} & \multirow{6}{*}{ Shandaweel-1 } & Atlantis & 42.23 & 21.77 & 49.53 \\
\hline & & Granstar +Topik & 43.03 & 18.23 & 35.37 \\
\hline & & Granstar + Axial & 44.93 & 19.10 & 42.30 \\
\hline & & Granstar + Traxos & 30.23 & 12.33 & 24.90 \\
\hline & & Hand weeding twice & 22.73 & 15.23 & 25.93 \\
\hline & & Unweeded & 258.53 & 142.20 & 367.87 \\
\hline & \multirow{6}{*}{ Sids-12 } & Atlantis & 45.63 & 27.97 & 54.90 \\
\hline & & Granstar +Topik & 41.33 & 22.77 & 46.67 \\
\hline & & Granstar + Axial & 47.80 & 25.63 & 50.20 \\
\hline & & Granstar + Traxos & 32.93 & 24.93 & 41.63 \\
\hline & & Hand weeding twice & 32.93 & 30.83 & 45.07 \\
\hline & & Unweeded & 302,63 & 170.67 & 428.03 \\
\hline & \multirow{6}{*}{ Giza-168 } & Atlantis & 37.23 & 19.70 & 35.93 \\
\hline & & Granstar +Topik & 28.67 & 15.10 & 27.00 \\
\hline & & Granstar + Axial & 36.43 & 18.27 & 34.83 \\
\hline & & Granstar + Traxos & 24.43 & 15.10 & 26.87 \\
\hline & & Hand weeding twice & 21.07 & 7.73 & 17.83 \\
\hline & & Unweeded & 224.47 & 124.30 & 241.40 \\
\hline L.S.D ${ }_{0.05}$ & & & 13.05 & 9.06 & 10.34 \\
\hline
\end{tabular}

Table 9. Correlation coefficients of grain yield(ard./fed) as influenced by yield components and dry weight of weeds in 2014/15 and 2015/16 seasons.

\begin{tabular}{|c|c|c|}
\hline \multirow{2}{*}{\multicolumn{3}{|c|}{$\begin{array}{l}\text { Characters } \\
\text { Grain vield (ardab/fed) }\end{array}$}} \\
\hline & & \\
\hline 1-Plant height $(\mathrm{cm})$ & $0.201^{\mathrm{ns}}$ & $0.175^{\mathrm{ns}}$ \\
\hline 2-Spike length $(\mathrm{cm})$ & $0.922^{* * *}$ & $0.914^{* * *}$ \\
\hline 3-No. spikelets/spike & $0.529^{* *}$ & $0.588^{* *}$ \\
\hline $4-$ No. of spikes $/ \mathrm{m}^{2}$ & $0.651^{\text {** }}$ & $0.872^{* *}$ \\
\hline 5- Weight of grains /spike (g) & $0.339^{*}$ & $0.557^{* *}$ \\
\hline 6 -Spike weight $(\mathrm{g})$ & $0.465^{\text {** }}$ & $0.855^{* *}$ \\
\hline 7-No. of grains/spike & $0.746^{* *}$ & $0.684^{* *}$ \\
\hline 8 -1000-seed weight (g) & $0.489^{* *}$ & $0.391^{* *}$ \\
\hline 9-Grassy weeds & $-0.598^{* *}$ & $-0.654^{* *}$ \\
\hline 10-Broad -leaved weeds & $-0.495^{* *}$ & $-0.587^{* *}$ \\
\hline 11-Total leaved weeds & $-0.565^{* *}$ & $-0.607^{* *}$ \\
\hline
\end{tabular}

*and**: Significant at 0.05 and 0.01 probability levels, respectively. ns: not significant

\section{D- Economics of crop production:}

Table 10 showed that the cost of all operation included in the production of wheat crop was calculated/fed (4169.00 L. E/fed)i.e. land preparation, seeding and planting, fertilizers, water rates, insect control, harvesting and land rent/fed and average random cost was about 300, 305, 580, 360 and 400 L.E. /fedfor using $\left(\mathrm{T}_{1}\right),\left(\mathrm{T}_{2}\right),\left(\mathrm{T}_{3},\left(\mathrm{~T}_{4}\right)\right.$ and $\left(\mathrm{T}_{5}\right)$.Thegreatest gross, net income and $\mathrm{B} / \mathrm{C}$ ratio was recorded withcultivar Giza.168, (8649.52 L. E/fed, 4131.35 L.E/fed and 1.91)followed by Shandaweel-1 (8336.16 L.E/fed 3817.99 L.E/fed and 1.85), while the lowest was in sids-12, (8025.07 L.E./fed, 3506.90 L.E/fed and 1.78 ), respectively might by due to higher grain yields observed in the seed rate of at $60 \mathrm{Kg}$ seed/fed was recorded the highest gross, net income and $\mathrm{B}: \mathrm{C}$ ratio, it might be due to higher grain yield recorded than in 50 $\mathrm{Kg}$ seed/fed.Data inTable 10 indicated that the highest gross income (8988.57 and 8796.21 L.E/fed), net income (4394.57 and 4242.21 L.E. /fed) and B: Cratios (1.96 and 1.93) were recorded from $\left(\mathrm{T}_{5}\right)$ which was closely followed by with application of Granstar and Traxos treatment. The lowest gross income 7296.47 L.E/fed, net income 3102.47 L. E/fed and 1.74 B: C ratio were recorded from unweeded treatment. The average of gross income/fed of wheat yield ranged from about 7037.65 L.E. to about 9704.70 L.E. with interaction among a $2 x b 3 x c 5$ and with interaction among a1xb1xc6 as minimum and maximum values. The average of net income of wheat yield/fed recorded about 5085.70 L. E/fed with interactionamong a2xb3xc5. While, thelowest values with interactionamong a1xb2xc6 about 2548.85 L.E. /fed Also, the trend of B: $\mathrm{C}$ ratio is the same interaction. 
Table 10. Total costs, gross income, net income (L.E/fed.) and Benefit: cost ratio as affected by seeding rates, wheatcultivars and weed control treatments (average of two seasons).

\begin{tabular}{|c|c|c|c|c|c|c|}
\hline \multicolumn{3}{|c|}{ Treatments } & \multirow{2}{*}{$\begin{array}{l}\text { Total costs } \\
\text { L.E/fed }\end{array}$} & \multirow{2}{*}{$\begin{array}{l}\text { Gross income } \\
\text { L.E/fed }\end{array}$} & \multirow{2}{*}{$\begin{array}{l}\text { Net income } \\
\text { L.E./fed }\end{array}$} & \multirow{2}{*}{$\begin{array}{l}\text { Benefit/cost } \\
\text { Ratio (B/C) }\end{array}$} \\
\hline (A) & (B) & (C) & & & & \\
\hline \multirow{18}{*}{$\begin{array}{l}50 \\
\mathrm{Kg} / \mathrm{fed} \\
\text { (a1) }\end{array}$} & \multirow{6}{*}{$\begin{array}{l}\text { Shandaweel1 } \\
\text { (b1) }\end{array}$} & Atlantis (c1) & 4469.00 & 7550.15 & 3081.15 & 1.69 \\
\hline & & Granstar +Topik (c2) & 4474.00 & 8124.15 & 3650.15 & 1.82 \\
\hline & & Granstar + Axial (c3) & 4749.00 & 7878.15 & 3129.15 & 1.66 \\
\hline & & Granstar + Traxos (c4) & 4529.00 & 8536.20 & 4007.20 & 1.88 \\
\hline & & Hand weeding twice (c5) & 4569.00 & 8665.35 & 4096.35 & 1.90 \\
\hline & & Unweeded (Control). (c6) & 4169.00 & 7037.65 & 2868.65 & 1.69 \\
\hline & \multirow{6}{*}{$\begin{array}{l}\text { Sids12 } \\
\text { (b2) }\end{array}$} & Atlantis (c1) & 4469.00 & 7195.50 & 2726.50 & 1.61 \\
\hline & & Granstar +Topik (c2) & 4474.00 & 7708.00 & 3234.00 & 1.72 \\
\hline & & Granstar + Axial (c3) & 4749.00 & 7535.80 & 2786.80 & 1.61 \\
\hline & & Granstar + Traxos (c4) & 4529.00 & 8214.35 & 3685.35 & 1.81 \\
\hline & & Hand weeding twice (c5) & 4569.00 & 8413.20 & 3844.20 & 1.84 \\
\hline & & Unweeded (Control). (c6) & 4169.00 & 6717.85 & 2548.85 & 1.61 \\
\hline & \multirow{6}{*}{$\begin{array}{l}\text { Giza168 } \\
\text { (b3) }\end{array}$} & Atlantis (c1) & 4469.00 & 7796.15 & 3327.15 & 1.74 \\
\hline & & Granstar +Topik (c2) & 4474.00 & 8562.85 & 4088.85 & 1.91 \\
\hline & & Granstar + Axial (c3) & 4749.00 & 8212.23 & 3463.23 & 1.73 \\
\hline & & Granstar + Traxos (c4) & 4529.00 & 8706.35 & 4177.35 & 1.92 \\
\hline & & Hand weeding twice (c5) & 4569.00 & 8767.85 & 4198.85 & 1.92 \\
\hline & & Unweeded (Control). (c6) & 4169.00 & 7455.85 & 3286.85 & 1.79 \\
\hline \multicolumn{3}{|c|}{ Mean of A1 } & 4493.17 & 7948.76 & 3455.59 & 1.77 \\
\hline \multirow{18}{*}{$\begin{array}{l}60 \\
\mathrm{Kg} / \mathrm{fed} \\
(\mathrm{a} 2)\end{array}$} & \multirow{6}{*}{$\begin{array}{l}\text { Shandaweel1 } \\
\text { (b1) }\end{array}$} & Atlantis (c1) & 4519.00 & 8472.65 & 3953.65 & 1.87 \\
\hline & & Granstar + Topik (c2) & 4524.00 & 9020.00 & 4496.00 & 1.99 \\
\hline & & Granstar + Axial (c3) & 4799.00 & 8767.85 & 3968.85 & 1.83 \\
\hline & & Granstar + Traxos (c4) & 4579.00 & 8993.35 & 4414.35 & 1.96 \\
\hline & & Hand weeding twice (c5) & 4619.00 & 9471.00 & 4852.00 & 2.05 \\
\hline & & Unweeded (Control). (c6) & 4219.00 & 7517.35 & 3298.35 & 1.78 \\
\hline & \multirow{6}{*}{$\begin{array}{l}\text { Sids12 } \\
\text { (b2) }\end{array}$} & Atlantis (c1) & 4519.00 & 8138.50 & 3619.50 & 1.80 \\
\hline & & Granstar + Topik (c2) & 4524.00 & 8718.65 & 4194.65 & 1.93 \\
\hline & & Granstar + Axial (c3) & 4799.00 & 8507.50 & 3708.50 & 1.77 \\
\hline & & Granstar + Traxos (c4) & 4579.00 & 8849.85 & 4270.85 & 1.93 \\
\hline & & Hand weeding twice (c5) & 4619.00 & 8909.30 & 4290.30 & 1.93 \\
\hline & & Unweeded (Control). (c6) & 4219.00 & 7392.30 & 3173.30 & 1.75 \\
\hline & \multirow{6}{*}{$\begin{array}{l}\text { Giza168 } \\
\text { (b3) }\end{array}$} & Atlantis (c1) & 4519.00 & 8829.35 & 4310.35 & 1.95 \\
\hline & & Granstar + Topik (c2) & 4524.00 & 9585.80 & 5061.80 & 2.09 \\
\hline & & Granstar + Axial (c3) & 4799.00 & 9143.00 & 4344.00 & 1.91 \\
\hline & & Granstar + Traxos (c4) & 4579.00 & 9477.15 & 4898.15 & 2.07 \\
\hline & & Hand weeding twice (c5) & 4619.00 & 9704.70 & 5085.70 & 2.10 \\
\hline & & Unweeded (Control). (c6) & 4219.00 & 7658.80 & 3439.80 & 1.82 \\
\hline \multicolumn{3}{|c|}{ Mean of A2 } & 4543.17 & 8725.07 & 4427.73 & 1.92 \\
\hline \multirow{3}{*}{\multicolumn{2}{|c|}{ Mean of B }} & Shandweel-1 (b1) & 4518.17 & 8336.16 & 3817.99 & 1.85 \\
\hline & & Sids-12 (b2) & 4518.17 & 8025.07 & 3506.90 & 1.78 \\
\hline & & Giza-168 (b3) & 4518.17 & 8649.52 & 4131.35 & 1.91 \\
\hline \multirow{6}{*}{\multicolumn{2}{|c|}{ Mean of C }} & Atlantis (c1) & 4494.00 & 7997.05 & 3503.05 & 1.78 \\
\hline & & Granstar +Topik (c2) & 4499.00 & 8602.28 & 4103.28 & 1.91 \\
\hline & & Granstar + Axial (c3) & 4774.00 & 8340.76 & 3566.76 & 1.75 \\
\hline & & Granstar + Traxos (c4) & 4554.00 & 8796.21 & 4242.21 & 1.93 \\
\hline & & Hand weeding twice (c5) & 4594.00 & 8988.57 & 4394.57 & 1.96 \\
\hline & & Unweeded (Control). (c6) & 4194.00 & 7296.47 & 3102.47 & 1.74 \\
\hline \multicolumn{7}{|c|}{ Note: A- Average prevailing market prices of herbicides during $2014 / 2015$ to $2015 / 2016$} \\
\hline 1- Atli & tis $\quad 50$ & E/lit., 2-Axial & E/lit., 3 & $\begin{array}{lc}\operatorname{arox} & 300 \mathrm{~L} \\
\mathrm{n}=410 & \mathrm{~L}\end{array}$ & $\begin{array}{l}\text { it., } \quad 4-\mathrm{To} \\
\text { ing season } 2\end{array}$ & 70 L.E/100g \\
\hline
\end{tabular}

\section{REFERENCES}

Abbas,S.H.; S. Muhammad ; M. K. Muhammad ; M.M. Yaqub ; H. Mahmood, and S.Rashid (2009). Weed density and grain yield of wheat as affected by spatial arrangement and weeding techniques under rain fed conditions of Pakistan. J.of Agric.Sci., 46(4):354-359.

Abd-Alla, M.M. and A.H.Bassiouny(1994). Response oftwo wheat cultivars to various planting densities. Egypt.J.Appl.Sci.9 (8):836-849.
Abd El-Ghany, H. M. ; E.A El-Housini and M.H. M. Afifi(2013). Effect of certain macronutrients foliar application on growth, yield and nutrients content of grains for two bread varieties in sandy soil.J.Appl.Sci.Res. 9(2):1110-1115.

Abouziena,H.F.; A.A. Sharara and E.R.El-desoki (2008). Efficacy of cultivars selectivity and weed control treatments on wheat yield and associated weeds in sandy soil. World,J.Agron. and Sci., 4(3):384-389. 
Abdrabbo,M.A.A.; F.A.Hashem and A.F.Abdou-Hadid (2016).Irrigation requirements for some bread wheat cultivars in relation to planting dates. J. Agric. Sci. and Res., 3(1):23-40.

Ahmed, S.; G.Hasina;S.Beene; H.Bibi; L.B. Nishat and P. Latafat (2012).Response of wheat to different planting dates and seeding rates for yield and yield components.Arpn,J.of Agric. and Bio.Sci.,7(2):138140.

Ali,M.; Ali, L. ; M. Sattar and M. A. Ali (2010). Improvement in wheat (Triticum aestivium L.) yield by manipulating seed rate and row spacing in Vehaizone.J.Anim and Plant Sci.,(20):225-230.

Amanullah, Z.; K.Ahmed, and D.Jan (2008).Performance of wheat cultivars sown at different seeding rate under drought stress conditions. Archives of Agron. and soil Sci. (56):99-105.

Amit, J.J.; S.C.Shah;H.R.Paresh and H.Bhatt(2008). Integrated effect of seed rates and weed management treatments in wheat (Triticum aestivium L.).Res.J.Agric and Biol.Sci. 4(6):704711.

Ashrafi, Z.Y.; A.Rahnavard and S.Sedigheh(2009). Analogy potential effects of planting methods and tank mixed herbicides on wheat yield and weed population. J. of Aric.Technology, 5(2):391-403.

Bibi,K.B.;G.Hassan and N.K.Maula (2008). Effect of herbicides and wheat population on control of weeds in wheat.PakistanJ. of weed Sci.Res.,14(34):111-119.

CIMMYT (1988). From agronomic data to farmer recommendation: an economic work book D.F:3133.

El-Ganayni,A.A. and G.A.Mahmoud (2008). Productivity of tow bread wheat cultivars under three seeding rates. J.Agric.Sci., Mansoura Univ.,33(6):3993-4000.

El-Metwally,I.M. and H.S.Saudy (2009). Herbicides tank-mixtures efficiency on weeds and wheat productivity. In Annals of Agric.Sci., Moshtohor 47(2):95-109.

El-Metwally,I.M.; M.S.Abd El-Salam and R.M.H Tagour (2010). Nitrogen fertilizer levels and some weed control treatments effects on barley and associated weeds. In Agric. and Biology J. of North America, 1(5):992-1000.

Essam,A.A.(2014). Determining the optimization seeding rate for improved productivity of wheat under Southern Egypt conditions.Inter.J.Agro. and Agric.Res.,4(1):47-57.

El-Nady,H.E.A.(2009).Breeding bread wheat drought and earliness. Ph.D.Thesis,Fac.Agric., Mohtohor, Univ.,Egypt.

FAO, FAOSTAT, FAO Statistics Division 2016, March, 2016.

Fakkar, A. A. O. (2005). Efficiency of some weed control methods under different levels of nitrogen fertilizers in wheat. Ph. D. Thesis, Fac. Agric, El-Minia Univ., Egypt.

Geleta,B.;M.Atak;P.S.Baenziger;L.A.Welson;D.D.Balte nesperger;K.M.Eskridge;M.J. Shipnian and D.R.Sheton(2002). Seeding rate and use quality of winter wheat.Crop Sci., 42:827-832.
Genene,G.and S.Habtamu(2001). Agronomic research recommendation and seed production maintenance techniques for major crops training manual for DA of highland Bale Sinan-Ethiopia: 9-15.

Gomez, K.A. and A.A. Gomez(1984). Statistical procedures for Agricultural Research. 2nd Ed., John Wiley Son, New York, USA.

Gomma,A.S.A.(1999). Wheat improvement in Egypt: History and future prospects.Egypt.J.Plant Breeding, 3:1-14.

Hassan,M.A.(2008). Effect of seeding rate and row spacing on productivity and resistance to powdery mildew of tow bread wheat cultivars. Egypt.J.Appl.Sci. 23(10A):169-182.

Hayatullah, K.; A.K.Muhamad; H.Iqtidar and Z.KMuhammad (2000). Effects of sowing rates and methods on weed control and yield of wheat. Pakistan J. ofBio.Sci., 3(5):829-832.

Ibrahim, M.El.; A.M. Osama, and T.A. Magdi(2015). Response of wheat (Triticum aestivum L.) and associated grassy weeds grown in salt-affected soil to effects of graminicides and indole acetic acid. Agric.(polnohospodarstvo), 61(1):1-11.

Ibrahim, A. F.; KA.A.andil; A. H. El-Hattab and A. K. Eissa (2008) Effect of sowing date and weed control on grain yield and its Components in some wheat cultivars.J. of Agro. and Crop Sci., 157(3):199 207 .

Kandil,A.A.; A.E.M.Sharief; S.E. Seadh, and D.S.K Altai (2016). Role of humic acid and amino acids in limiting loss of nitrogen fertilizer and increasing productivity of some wheat cultivars grown undernewly reclaimed sandy soil.Int.J.Res.Bio.Sci. 3(4):123-136.

Khan, I.;G.Hassan and K.B. Marwat (2002). Efficacy of different herbicides for controlling weeds in wheat crop-II. Weed dynamics and herbicides. Pakistan J. Weed Sci. Res., 8(1-2):41-47.

Marwat, M.I.; H.K.Ahmad; K.B.Marwat and G.Hassan (2002). Integrated weed management in wheat. IWeed density, dry weed biomass, absolute growth rate and grain yield.Pakistan J.Weed Sci.Res., 8(1-2):81-93.

Marwat, M.I.;H.K.Ahmad;H.H. Khan, and A.Khan (2002a). Effect of weed management practices on economic traits on wheat. Online J. Biol. Sci., 2(11):722-724.

Mehasen,S.A.S.; M.A. Ahmed and M.A.M.Morsy (2014). Evaluation of some wheat genotypes under different seeding rates.Egypt.J.Appl.Sci. 19(2):129-150.

Meysam,B. and S.Saeed (2015). Effect of seed rate and post emergence herbicide application on weed infestation and subsequent crop performance of wheat (Triticum aestivum L.). Walla, J., 31(53):158-162.

Mondal,S.K. and M.R. Khajuria, (2001).Correlation and path analysis in bread wheat (Triticum aestivum L.) under rainfed conditions. Environment and Ecology, 18:405-408.

Omar,A.E.A.(2007). Productivity of some wheat cultivars as affected by sowing date and seeding rate. Egypt.J. Appl.Sci.22 (3):103-116. 
Pandey,J.; B.N. Mishra,and A.K.Verma (2001). Effect of varying doses of weedicides on yield attributes, yield and nitrogen uptake by wheat. J. Appl. Biol. 8:144-147.

Salahuddin;M.Akram and Alluddin (2016). Impact of various herbicides on dicot weeds in wheat (Triticum aestivum L.).Current Sci. perspectives 2(3):45-51.

Shehzad, M.A.; M.A. Nadeem and M. Iqbal (2012). Weed control and yield attributes against postemergence herbicides application in wheat crop, Punjab, Pakistan. In Global Advanced Res. J. of Agric. Sci., 1(1):7-16.

Steel, R. G. D and ,J. H. Torrie (1980).Principles and procedures of statistics. MC Graw Hill Book Company Inc.NEW york,481 pp.

Tagour, R. M. H.; G. M. Abd El-Hamed and I. M. ElMwtwally (2011). Improving herbicides efficacyof topik and traxos on wheat plants and associated weeds by adjuvants Arkopal. In Nature and Sci., 9(11):176-183.
Tasfay,A.; J.J. Sharma andZ. Kassahun(2011). Effect of weed control methods on weeds and wheat (Triticum aestivum L.) yield. World,J.of Agric.Res.,2(3):124128.

Tomar,S.K.(2004). Response of rain fed wheat to sowing methods and seed rate under Diara land conditions.Madras,Agric.J. 91:47-51.

Tompkins,D.K.; D.B. Fowler and A.T.Wright(1991b). Water use by no-till winter wheat. Influence of seed rate and row spacing.Agron.J., (83):766-769.

Tompkins,D.K; G.E Hultgreen; A.T. Wright and D.B. Fowler (1991a). Seed rate and row spacing of notill winter wheat. Agron.J. 83:684-689.

Yasin,M.;A.Tanveer; Z.Iqbal and A.Ali (2010).Effect of herbicides on narrow leaved weeds and yield of wheat (Triticum aestivum L.). International J.of Biological, Bimolecular, Agricultural, food and Biotechnological Engineering, 4(8):619-621.

Zoheir,Y.A.;S.Sadeghi and H.R.Mashhadi(2009). Study of integrate methods chemical and cultural control of weeds to wheat (Triticum aestivum L.).J.Agric.Sci., 1(2):113-119.

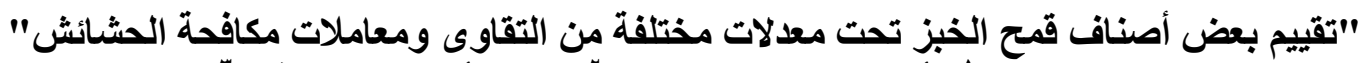

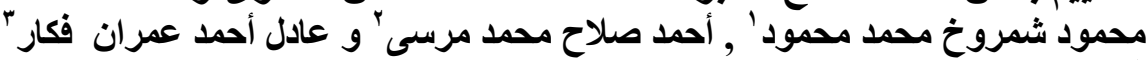

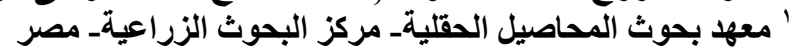

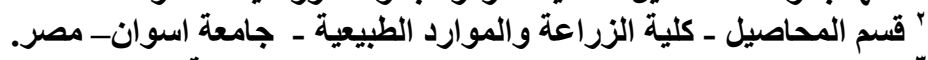

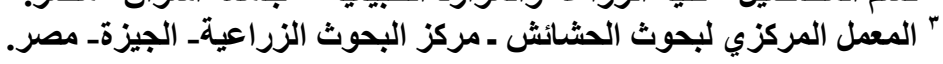

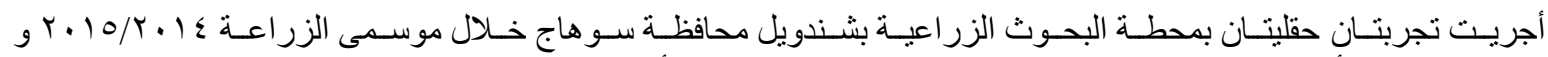

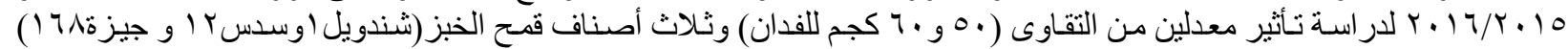

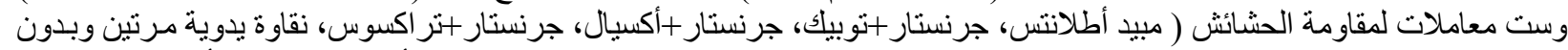

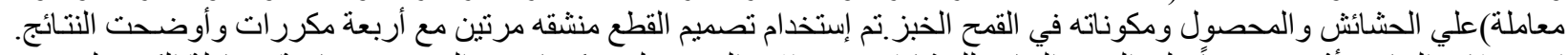

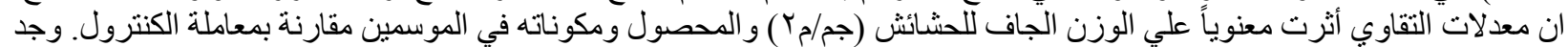

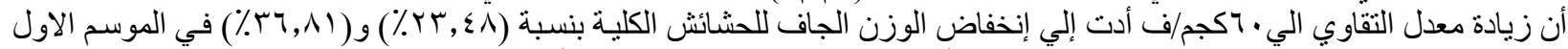

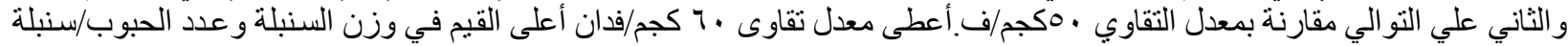

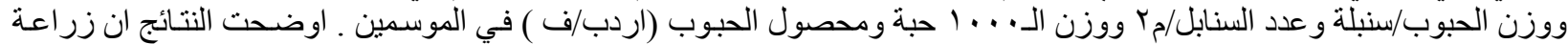

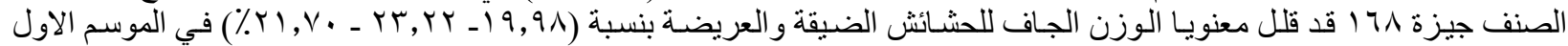

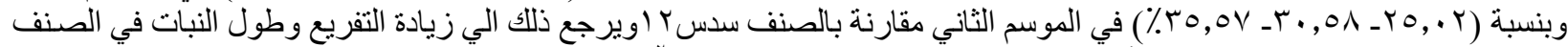

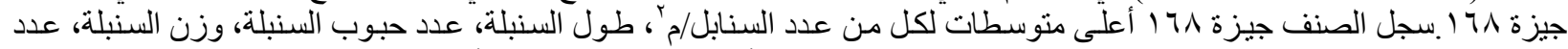

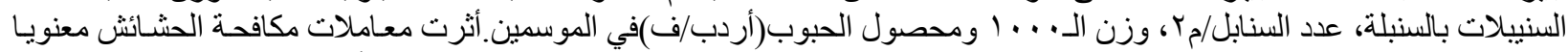

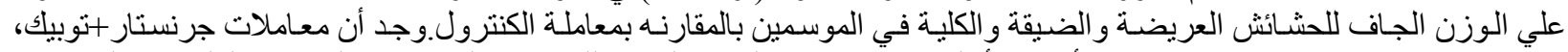

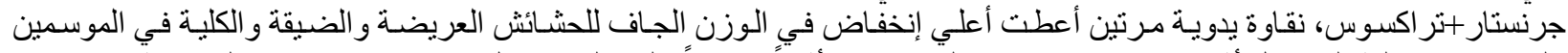

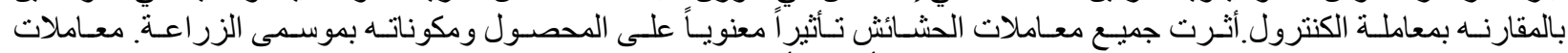

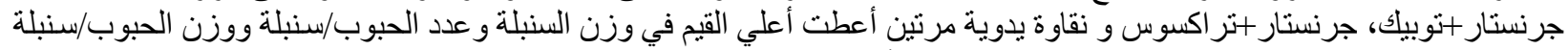

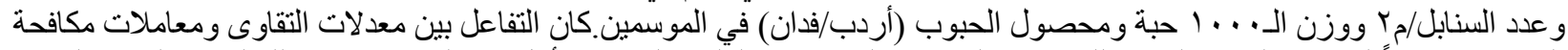

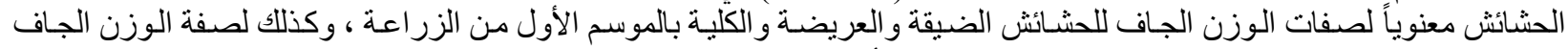

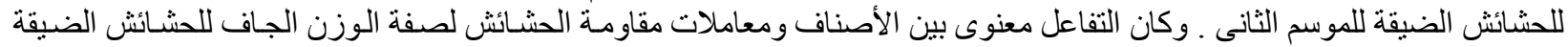

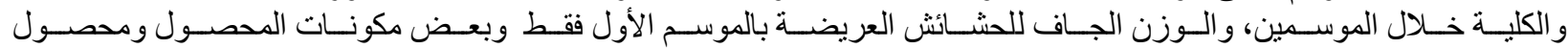

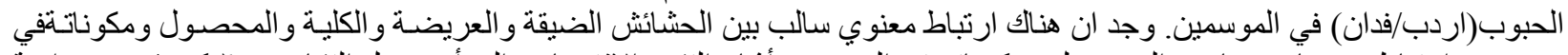

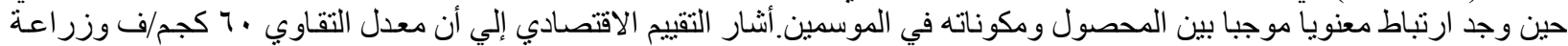

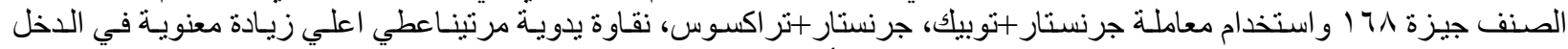

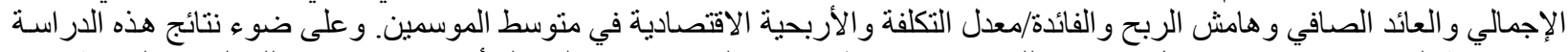

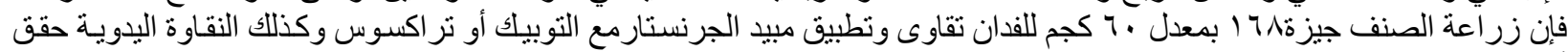
أفضل محصول من القمح خلال الموسمين تحت منطقة الدر اسة. 